\title{
Role of placentally produced inflammatory and regulatory cytokines in pregnancy and the etiology of preeclampsia
}

\author{
Corinne Rusterholz • Sinuhe Hahn • \\ Wolfgang Holzgreve
}

Received: 15 February 2007 / Accepted: 28 March 2007 / Published online: 19 April 2007

(C) Springer-Verlag 2007

\begin{abstract}
Human pregnancy is a metabolic and immune challenge for the mother who has to accommodate in her womb a semi-allogeneic fetus whose energy needs increase tremendously with gestation. Recent compelling research has suggested that proper inflammatory changes and oxidative balance are a requisite for successful pregnancy. The placenta is an integral component of this inflammatory response as it actively produces a variety of cytokines and immunomodulatory hormones. In preeclampsia, a lifethreatening disorder of pregnancy that is characterized by widespread damage and dysfunction of the maternal endothelium, placental oxidative stress and aberrant cytokine expression induces an exaggerated maternal systemic inflammatory response to pregnancy.
\end{abstract}

Keywords Pregnancy P Preeclampsia - Placenta .

Cytokines $\cdot$ Inflammatory response

\section{Introduction}

Human pregnancy imposes a massive stress to the maternal body, which has to accommodate the increasing energy needs of the developing fetus at the expense of its own needs. Therefore, several physiologic and metabolic changes take place in the maternal body to adapt to such a challenge. The most striking physiologic alteration during

C. Rusterholz $(\bowtie) \cdot$ S. Hahn $\cdot$ W. Holzgreve

Laboratory for Prenatal Medicine and Gynecologic Oncology,

University Women's Hospital/Department of Research,

University of Basel,

Hebelstrasse 20,

Basel 4031, Switzerland

e-mail: crusterholz@uhbs.ch pregnancy, apart from the evident weight gain as a consequence of fat and protein deposition in maternal stores, is the increase in blood volume, which is needed for extra blood flow to the uterus and increased perfusion of other organs, especially the kidneys. The pregnant uterus undergoes important tissue and vascular remodeling, the most remarkable of which is the transformation of the uterine spiral arteries into low-resistance flow vessels that enable large volumes of blood to gain access to the placental intervillous space [1]. Additional metabolic changes, such as increased red blood cell counts, insulin resistance and elevated cardiac output further guaranty that the placental villous tree bathes in a nutrient- and oxygenrich milieu.

The success of pregnancy requires an appropriate immunological interplay between the mother and the developing fetus, as the latter, which expresses paternal antigens, is considered to be a semi-allograft to the maternal immune system [2]. Thus, mechanisms have developed to allow the fetal entity to escape from maternal immune attack, and above all, avoid rejection. To begin with, the fetus is physically secluded from the maternal immune system by the protective shell of embryonic trophectodermderived trophoblast cells, which make up the placenta and the chorionic membrane. Most interestingly, the placenta has been identified as a site of immune privilege. This tissue is the source of production of many immunomodulatory hormones and cytokines, and one prevalent hypothesis is that several of these factors released at the feto-maternal interface or into the maternal blood stream contribute to the regulation of the local and systemic immune changes required for a successful pregnancy. By contrast, aberrant placental production of these factors has been shown to be associated with pregnancy-related disorders or even failed pregnancies. The action of several cytokines in the success of 
pregnancy and in the development of preeclampsia will be reviewed here.

\section{The immunology of pregnancy}

The placenta, which is in direct contact with maternal cells in the uterine wall and with maternal blood, is an important immunological barrier between maternal and fetal antigens. This tissue lacks expression of the conventional polymorphic major histocompatibility molecules (MHC) class I, human leukocyte antigen (HLA)-A and HLA-B, and class II [3], and thus, is protected from cytotoxic T lymphocyte (CTL)-mediated destruction. To avoid killing by natural killer (NK) cells, which are programmed to recognize HLA-null cells, trophoblast cells express instead a combination of the nonclassical MHC molecules HLA-G [4], HLA-E, and HLA-F [5]. Whereas the role of HLA-F in pregnancy still awaits elucidation, accumulating research has provided convincing evidence that HLA-G and HLA-E possess immunosuppressive properties, especially towards NK cells and subsets of T lymphocytes, and the idea that placental HLAs facilitate pregnancy, in part, by inhibiting maternal immune cytotoxic responses towards placental cells is now well established [6,7]. However, a different regulatory mechanism must apply to decidual NK cells, which constitute 50 to $70 \%$ of all maternal immune cells present in the pregnant uterus, as these cells do not appear to possess lytic activity [8]. Instead, they are thought to positively regulate pregnancy through secretion of cytokines and angiogenic factors, which have crucial actions on the vascular and decidual transformations occurring in the uterine wall during the early weeks of pregnancy [9-11]. Nevertheless, their regulation might also be mediated by HLA-G and by HLA-C, also present in high amounts on extravillous trophoblasts invading the pregnant uterus [12, 13].

In addition to strategies conferring a relative immune "invisibility" to the placenta, adjustments in the maternal immune system have been suggested to help in sustaining a successful pregnancy. The concept of a maternal CD4positive $\mathrm{T}$ helper cell (Th) 2-biased immunity in pregnant women has been appreciated for over a decade [14]. Th2 immunity is characterized by the dominance of humoral immune responses over cell-mediated, more destructive responses, more likely to be detrimental to the fetal allograft. CD4-positive Th2 lymphocytes develop from naïve $\mathrm{T}$ helper cells in the presence of interleukin (IL)-4 and IL-10, whereas Th1 cells arise when IL-2 and interferon (IFN)- $\gamma$ are present. In turn, Th1 and Th2 lymphocytes express a panel of membrane-bound or soluble immunomodulatory mediators, which influence the activity of other cells of the adaptive immune system, therefore controlling the immune response. A type 2 bias seems to take place both in the intrauterine milieu and in the systemic maternal circulation during pregnancy. It has been reproducibly demonstrated that the placental bed encloses a high incidence of the Th2 factors IL-4 and IL10 [15-19]. Several isoforms of the immunosuppressive transforming growth factor (TGF) $\beta$ have also been localized in the placenta, adding to the immune privilege of this tissue [20-22]. Trophoblast cells themselves contribute to the generation of this cytokine milieu as they spontaneously secrete these immunoregulatory molecules, locally, but also into the intervillous space where these may likely participate in the constitution of the peripheral type 2 response. By contrast, type 1 cytokines appear to be marginally expressed or completely absent from the feto-maternal interface [23, 24]. Moreover, the profile of cytokine synthesized by maternal peripheral blood lymphocytes during pregnancy further sustains the development of type 2 immune responses [25]. Conversely, failure to generate a Th2 cytokine milieu, or alternatively, a Th1 cytokine environment has been associated with poor pregnancy outcome [26-28]. However, this long-standing paradigm has been recently disputed [29], as the networks of cytokines targets and actions have become increasingly intricate.

\section{Normal pregnancy and inflammation}

A series of intriguing findings have lead to the suggestion that pregnancy is, in fact, a condition of controlled mild maternal systemic inflammation, during which cells of the innate immune system display activated phenotypes [3032] and circulating levels of particular pro-inflammatory cytokines, such as tumor necrosis factor (TNF) $\alpha$, IL-6, and IL-1 are raised compared to nonpregnant women [33, 34]. By some aspects, the inflammatory changes in peripheral blood leukocytes were found to be similar to those occurring in patients with sepsis [30]. In addition, monocytes from normal pregnant women were shown to be primed to produce the potent Th1 cytokine IL-12 [35], fueling the debate on the strict dependence on a type 1 vs type 2 adaptive immunity in pregnancy. What is more confounding is the fact that trophoblast cells as well appear to be the source of production of these pro-inflammatory cytokines [36-41]. In vitro, in a dually perfused placental cotyledon, most of placental TNF $\alpha$ was released to the maternal side [42], confirming the importance of placentally produced inflammatory mediators in the induction of the maternal systemic changes. Yet, generalized maternal inflammation is not associated with illness in pregnancy, but has been suggested to be part of the mother's adaptation to pregnancy and might be crucial for successful pregnancy 
by not only potentially compensating for a suppressed maternal adaptive immune system and therefore help protect against infection, but also by promoting the physiologic and metabolic changes taking place in the mother's body [43].

\section{Preeclampsia}

Preeclampsia is a serious complication of the second half of human pregnancy, which can have harmful effects on the immediate and long-term health of the mother and the baby $[44,45]$. This disease is characterized by multiple maternal disturbances, among which the more prominent symptoms are de novo hypertension, proteinuria, and edema. Additional metabolic dysfunctions may be present, such as activation of the clotting system, impaired liver function, renal failure or pulmonary edema, in particular, in cases of severe, early onset disease [46]. In the absence of intervention, preeclampsia can progress in generalized convulsions or eclampsia. The symptoms resolve only once the placenta is removed, and thus, preeclampsia remains one of the most common reasons for induced preterm delivery.

While the etiology of the disorder is still elusive, it is quite clear that it requires a placenta to develop. Risk factors are known and include primiparity, multiple pregnancies, a previous history of preeclampsia, and chronic medical conditions such as obesity, hypertension, vascular disease, or diabetes [47]. However, there is no definitive predictive factor and no preventive treatment available so far. There may undoubtedly be a genetic component at the basis of some cases of preeclampsia, at least in those with a familial history [48, 49]. However, such a genetic cause has not been convincingly demonstrated until now, most likely because polymorphisms in not only one but in several genes are likely to predispose to the development of this complex multifactorial disease. On the other hand, recent work clearly reveals that immune maladaptation and overt activation of the maternal innate immune system are involved in preeclampsia [50, 51]. Remarkably, although the maternal symptoms of preeclampsia appear very heterogeneous at first sight, they can all be ascribed to a generalized endothelium dysfunction [52], which is undeniably part of this exaggerated systemic inflammatory response to pregnancy [53].

\section{Two-stage model of the disease}

The symptomatic phase of the disease is, in reality, the second step of a two-stage pathological process, which has its origins in the placenta and occurs during the first weeks of pregnancy $[54,55]$. There is evidence of inadequate immunological interactions at the feto-maternal interface already very early in pregnancy. It has been described that HLA-G is under-expressed in preeclamptic placentas [5658], whereas certain combinations of placental HLA-C and their receptors on maternal $\mathrm{NK}$ cells appear to be selectively linked to the risk of developing the disease $[13,59]$. Moreover, the number and distribution of macrophages in placental beds are significantly altered in preeclampsia in comparison to normal pregnancy [60-62]. Furthermore, it was also shown that activated macrophages have the potential to induce apoptosis of extravillous trophoblasts in vitro [63]. Increased trophoblast cell death is believed to be central to the impaired placentation that is observed in most cases of preeclampsia. These cells detach from the tip of the primitive trophoblastic outgrowths of the embryo, the anchoring villi, soon after embryo implantation, and actively invade the uterine wall around and into the spiral arteries, to initiate vessel remodeling and establish the uteroplacental circulation. In normal pregnancy, extravillous trophoblasts migrate deep into the decidual part of the arteries and ultimately adopt an endothelial cell-like phenotype and replace their musculo-endothelial lining. The arteries are thus transformed into low-resistance, highflow channels that provide the appropriate blood flow to the fetus. Preeclampsia is associated with widespread apoptosis of cytotrophoblasts that invade the uterus [64]. Correspondingly, extravillous trophoblasts invasion is abnormally shallow, and the remodeling and enlargement of the spiral arteries is restricted to their placental-proximal part [65, 66].

It has been hypothesized that as a consequence of failed remodeling, blood supply to the placenta is greatly reduced, and this may trigger placental hypoxia [67, 68]. An alternative interpretation of the histopathologic findings has proposed that after incomplete modification of the spiral arteries by the extravillous cytotrophoblasts, these retain a certain capacity to contract in their myometrial part. Phases of contraction followed by relaxation would then lead to cycles of hypoxia/reoxygenation within the placenta [69]. Whatever mechanism at play, the end result would be placental oxidative stress and dysfunction.

Oxidative stress occurs when the cellular levels of reactive oxygen species (ROS) exceed the cell antioxidant capacities. It has been reproducibly observed that ROS are increased, and the levels of several detoxifying enzymes are reduced in preeclamptic placentas, leading to damage of cellular lipids and various other cellular components [7074]. Moreover, in vitro triggered oxidative stress of a trophoblast cell line reproduced the placental abnormalities of preeclampsia [75]. Deficient oxygenation and increased oxidative stress most probably occur as early as week 10 12 of gestation when maternal blood first gains access to 
the placenta; however, the antioxidant capacity of placental cells might counteract or contain the insult for some time, until the levels of ROS, by far, surpass the placental redox capacity. Subsequently, placental damage and dysfunction becomes disproportionate. Hence, preeclamptic placentas are often aberrantly structured, with histological evidence of vasculitis, thrombosis, and areas of ischemic or necrotic tissue. These placentas also exhibit increased trophoblast apoptosis [76, 77], a feature that can be reproduced in vitro in models of placental hypoxia or hypoxia/reoxygenation [78-80]. It has been proposed that unusual loads of placental debris and toxic factors, among which proinflammatory cytokines, are released in the intervillous space, and in turn, interact with maternal endothelium and cells of the innate immunity, causing the vast array of maternal symptoms that distinguish the disease [81]. We and others have shown that the amount of placental debris, such as cell-free apoptotic DNA [82, 83] and syncytial microparticles, is indeed elevated in peripheral blood of women with preeclampsia $[84,85]$.

\section{Cytokines in preeclampsia}

It is generally agreed that preeclampsia is associated with both local and systemic changes in type 1/type 2 cytokine balance compared to normal pregnancy. Decidual lymphocytes and peripheral blood mononuclear cells from patients with preeclampsia are generally primed to synthesize high levels of the Th1 cytokines, IL-2, IL-12, and IFN- $\gamma$ [8689]. On the other hand, they exhibit low spontaneous or phytohemaglutinin-induced expression of the Th2 cytokines IL-10 and IL-5 [90-92]. Whereas these findings initially lead to the conclusion that a maternal $\mathrm{T}$ lymphocyte-mediated cytotoxic reaction against the fetal allograft was possibly associated with, and maybe the cause of preeclampsia, it is now believed that such a cytokine environment rather reflects the state of exaggerated inflammation that characterizes the disease. Monocytes and granulocytes present an activated pattern of leukocyte adhesion molecules on their surface and show an increased incidence of basal or induced oxidative stress response compared to their counterparts from normal pregnancy [30, 93]. Spontaneous monocytic cytokine expression is higher in preeclampsia in comparison with normal pregnancy [94]. This is mirrored in the maternal plasma cytokine environment. The circulating levels of TNF $\alpha$ and IL-6, which are already more elevated in healthy pregnant women compared to nonpregnant controls, are further raised in patients with preeclampsia [95-98]. There are also numerous reports of increased serum or plasma levels of several other pro-inflammatory cytokines and of their modulators, such as, IL-2, IL-8, IL-12, IL-15, IL-18, IL-1 receptor antago- nist, soluble IL-4 receptor, and soluble TNF receptor (Table 1) [96, 99-104]. The increased levels of soluble cytokine receptors found in patients with preeclampsia may represent a protective response to increased cytokine activity and be a marker for overt inflammation. However, these findings remain very controversial as others did not detect alterations in the levels of pro-inflammatory molecules between healthy pregnant controls and preeclamptic patients [104-106]. Of course, plasma cytokine milieu does not reflect the strict contribution of the placenta, as cytokine production by the dysfunctional maternal endothelium and peripheral blood mononuclear cells is obvious. However, it is undoubted that placental contribution is likely to be significant, as cytokine imbalance and elevated expression of pro-inflammatory molecules is also evident in preeclamptic placentas. Increased production of $\mathrm{TNF} \alpha, \mathrm{IL}-1$, and IFN- $\gamma$ has been documented in these placentas [107-110].

\section{Oxidative stress and placental production of pro- and anti-inflammatory cytokines}

A recent set of data has demonstrated that placental expression of many cytokines and soluble mediators of inflammation is tightly regulated by the oxygen tension and cellular oxidative stress that are imposed on the tissue. They provide, therefore, a direct link between the aberrant placental tissue oxygenation and altered cytokine patterns observed in preeclamptic placentas. It was shown that explants of placental villous tissue, derived from normal term placentas, significantly enhance their production of $\mathrm{TNF} \alpha$, IL- $1 \alpha$, and IL-1 $\beta$ when they are incubated in hypoxia, in comparison with the levels produced upon incubation in normoxia [111, 112]. The expression levels of these cytokines are similarly raised under alternative culture conditions which reduced oxygen availability, such as in

Table 1 Placentally produced inflammatory and immunomodulatory cytokines in preeclampsia

\begin{tabular}{lll}
\hline Cytokines & In placenta $^{\mathrm{a}}$ & In peripheral blood \\
\hline TNF $\alpha$ & No change/increased & Increased \\
IL-1 & No change/increased & No change \\
IL-6 & No change/reduced & Increased \\
IL-8 & Increased & Increased \\
IFN- $\gamma$ & Increased & No change/increased \\
IL-12 & Reduced & Increased \\
IL-15 & Reduced & No change/increased \\
IL-10 & Reduced & No change/increased \\
IL-4 & No change & No change/reduced \\
\hline
\end{tabular}

${ }^{\mathrm{a}}$ Changes relative to normal pregnancy. Contradictory data are mentioned. 
the presence of an iron chelator or cobalt chloride. It is interesting to note that late first trimester villous tissue also responds to hypoxia by increasing pro-inflammatory cytokine secretion, whereas early first trimester villous tissue is relatively insensitive to the changes in oxygen tension [111]. Furthermore, villous explants derived from preeclamptic placentas were found to be equally sensitive to the effect of hypoxia on TNF $\alpha$ and IL-1 expression [113].

Hypoxia/reoxygenation also increases TNF $\alpha$ synthesis by placental villous tissue in vitro [114]. Notably, in this particular experimental setting, hypoxia/reoxygenation was shown to be a more potent inducer of cytokine secretion than hypoxia alone. Finally, chemicals which trigger placental oxidative stress also stimulates elevated $\mathrm{TNF} \alpha$ and IL-1 production by villous explants [112]. In this context, it is interesting to note that in the presence of the antioxidant vitamin $\mathrm{C}$, the secretion of $\mathrm{TNF} \alpha$ by term placental villous explants is significantly reduced by $20 \%$ (Fig. 1). In contrast, IL-1 $\beta$ secretion did not show such a regulation. This would suggest that therapeutic interventions with antioxidant agents could possibly be developed, even though clinical trials with vitamin supplementation have so far failed to prevent disease occurrence in women at increased risk [115, 116].

Whether IL-6 expression is also controlled by oxygen levels is still debatable. No hypoxia-driven changes in IL-6 synthesis by placental explants were documented. In contrast, isolated cytotrophoblast cells derived from preeclamptic placentas were shown to express higher levels of this molecule than their normal counterparts and to respond to hypoxia by further increasing IL-6 secretion [117]. These latter data seem to contradict the finding that preeclampsia is associated with decreased placental IL-6 production [113, 118].

It is interesting to note that placental expression of immunosuppressor cytokines also seems to be modulated by oxygen tension. Cytotrophoblasts isolated from preeclamptic placentas show a hypoxia-induced reduction in IL-10 synthesis [117]. This feature is in agreement with the description of deficient placental IL-10 production in preeclampsia $[119,120]$. Trophoblast expression of TGF $\beta 3$
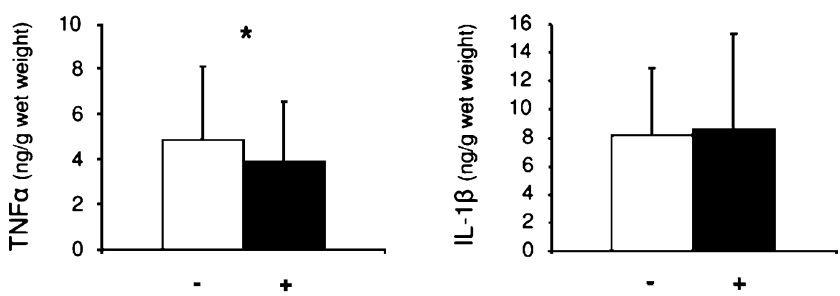

Fig. 1 Placental villous explants were cultured for $24 \mathrm{~h}$ in the absence $(-)$ or in the presence $(+)$ of vitamin $\mathrm{C}$ and levels of TNF $\alpha$ (left panel) and IL-1 $\beta$ (right panel) secreted in the culture supernatant were measured by enzyme linked immunosorbent assay and related to explant wet weight. Paired Student $t$ test was used. * $p<0.05, N=10$ is also regulated by oxygen tensions, in particular, during the switch from early to late first trimester. This gestational age-dependent dichotomy in cytokine production might be explained by the fact that early placental development takes place in the total absence of oxygen, as at that time, spiral arteries remodeling is not fully complete, and the intervillous space is largely devoid of blood flow. But by the end of the first trimester, maternal blood reaches the placenta, and TGF $\beta 3$ production is down-regulated [121]. In contrast, TGF $\beta 3$ remains overexpressed in preeclamptic placentas [122], a finding that may reflect the state of tissue oxidative stress, but could also participate in the development of later placental dysfunctions. Recently, it was shown that IFN- $\gamma$ synthesis by trophoblast cells similarly failed to switch from high to low expression as placental environment switches from early hypoxic to late normoxic condition [110].

\section{Cytokines and placentation}

During early pregnancy, the interstitial and endovascular trophoblast cells, which invade the decidua and the lumen of the uterine spiral arteries, respectively, differentiate from a fraction of highly proliferative extravillous trophoblast stem cells located in the anchoring villi. These differentiated cells express a new repertoire of adhesion molecules and secrete numerous proteinases, which enables their migration through the uterine stoma and along the endothelial lining of the vessels. In preeclampsia, invading trophoblast cells exhibit an altered protease expression profile and fail to acquire a vascular adhesion phenotype [123, 124]. Remarkably, the proliferation, invasion, and apoptosis of extravillous trophoblasts are orchestrated by several growth factors and almost all cytokines present in the intrauterine wall.

The switch in phenotype from a proliferative to an invasive state appears to be principally controlled by epidermal growth factor and hepatocyte growth factor $[125,126]$. This process is also very sensitive to oxygen tension [127], possibly because of the overproduction of cytokines and other mediators of angiogenesis by the extravillous trophoblasts themselves. For instance, IL- $1 \alpha$, IL- $1 \beta$, and IL- 6 have been described as positive regulators of trophoblast differentiation along the invasive pathway as these cytokines can stimulate matrix metalloproteinase (MMP) 9 and MMP2 expression and activity [128, 129]. Specifically, IL-1 $\beta$ expression was shown to parallel the invasive potential of cytotrophoblasts in vitro [130]. On the contrary, IL-10 and TGF $\beta$ inhibit trophoblast production of proteases and trophoblast invasion [131, 132]. Failure to down-regulate TGF $\beta 3$ expression in proliferative cytotrophoblasts has been linked to shallow placentation and 
predisposes the pregnancy to preeclampsia [122]. TNF $\alpha$ has also been implicated in the control of trophoblast cell fate. Notably, TNF $\alpha$, in combination with IFN- $\gamma$, stimulates apoptosis of cultured cytotrophoblasts and syncytiotrophoblasts $[133,134]$. This suggests a mechanism for deficient placentation in preeclampsia, where local concentrations of both cytokines are high. In contrast, conflicting results exist relative to the role of $\mathrm{TNF} \alpha$ in modulating extravillous trophoblast migration potential $[135,136]$. Nevertheless, the sum of these in vitro data suggests that the unbalanced placental expression of several cytokines early in pregnancies destined to develop preeclampsia likely plays a role in the etiology of the disease.

$\mathrm{TNF} \alpha$ also negatively affects the integrity of the syncytiotrophoblast layer by stimulating increased apoptosis in vitro [137]. Under normoxia, the underlying cytotrophoblasts were shown to reconstitute the syncytiotrophoblast. In contrast, when the placental environment was hypoxic, the syncytiotrophoblast failed to regenerate. $\mathrm{TNF} \alpha$ has also been reported to impair the syncytialization process [138]. Thus, in preeclampsia, increased production of $\mathrm{TNF} \alpha$ by trophoblast cells in response to deficient uteroplacental blood flow could, in an autocrine manner, lead to continuous syncytiotrophoblast damage and dysfunction. In addition, placental inflammation might be triggered locally, via the release of TNF $\alpha$ after adhesion of activated maternal monocytes to the syncytiotrophoblast [139].

The placental expression of several gestational hormones and mediators of metabolic pathways is also determined by the local cytokine milieu [140]. This area of research has been extensively studied in pregnancies affected with obesity or diabetes mellitus, but less in pregnancies complicated with preeclampsia. It is, nevertheless, likely that the dysregulated expression of these molecules is also occurring in preeclampsia as a result of the aberrant placental cytokine production pattern hallmarking this disease. However, this aspect will not be discussed here.

\section{Cytokines and feto-placental tolerance}

IL-10 and IL-4 are pleiotropic immunosuppressors, which display inhibitory effects on cytotoxic and inflammatory reactions. Their expression at the feto-maternal interface is suggested to help in counteracting the harmful effects of pro-inflammatory mediators on placental cells [141]. Remarkably, IL-10 also seems to be an important regulator of trophoblast survival, as it has been shown to selectively induces HLA-G expression in human cytotrophoblasts [142]. In line with these results, low IL-10 levels and diminished HLA-G expression have been observed in preeclampsia. Hence, deficient placental IL-10 expression might not only confer increased susceptibility to proinflammatory signals but also amplify inflammation-driven cell damage and NK cell-mediated trophoblast cell death. By opposition, increased trophoblast production of IFN- $\gamma$ may account for the altered decidual lymphocyte subset distribution and increased number of CD8-positive T cells in the placental bed $[143,144]$. IL- 6 bears both pro- and anti-inflammatory actions, depending on the cell type and cellular microenvironment it acts on. In the placenta, IL-6 appears to be a positive regulator of pregnancy, as trophoblast-derived IL- 6 acts in an autocrine manner on these cells to stimulate their secretion of the immunomodulatory hormone, human chorionic gonadotropin (hCG) [145]. However, serum levels of hCG are raised in preeclamptic patients despite decreased placental IL-6 production, and the role of IL- 6 in fetal tolerance awaits elucidation.

Another possible player in promoting fetal tolerance is the subset of $\mathrm{CD} 4^{+} \mathrm{CD} 25^{+}$regulatory $\mathrm{T}$ lymphocytes. These cells have been found to infiltrate the pregnant uterine wall and are, in fact, the second largest population of maternal immune cells present at the feto-maternal interface after uterine NK cells [146]. They function by dampening T cell mediated immune responses via the production of immunosuppressive cytokines [147], and they possibly play a role in the local maintenance of immune privilege [148]. Although preeclampsia is not associated with changes in the levels of regulatory $\mathrm{T}$ cells at the periphery [149], the cells may not perform adequately in this condition as $\mathrm{TNF} \alpha$, which is expressed in excess both at the fetomaternal interface and systemically, has been shown to inhibit their suppressive function in vitro [150]. Whether their numbers or activity is altered within the placentas of preeclamptic patients remain to be established.

\section{Cytokines and the maternal symptoms}

The endothelium plays a major role in several processes like the regulation of the coagulation cascade, the activation of platelets and leukocyte function, and is therefore an integral part of an inflammatory response. TNF $\alpha$ and IL-1 are the main pro-inflammatory cytokines that stimulate both structural and functional alterations in endothelial cells [151]. It has been suggested that placental IL-1 and TNF $\alpha$ could be potential mediators of maternal endothelial dysfunction in preeclampsia. The reasons for this are multiple. First, the circulating concentration of both cytokines is raised in pregnant women. In vitro, placentally produced IL-1 alters human umbilical vein endothelial cell proliferation and induces the secretion of soluble ICAM and IL-6 [152]. The latter are indeed found in increased levels in the peripheral blood of women with preeclampsia 
[153-155]. On the other hand, the elevated secretion of $\mathrm{TNF} \alpha$ by placental villous tissue in response to hypoxia/ reoxygenation causes a reduction of endothelial cell viability and up-regulates the expression of the adhesion molecule E-selectin by the endothelial cells [114]. Maternal serum from preeclamptic patients also stimulates the endothelial production of the vasoactive substances, endothelin-1 and prostacyclin, which might maintain or amplify maternal hypertension [156, 157]. According to recent research, hypertension might be initially triggered by the dysregulated placental production of the angiogenic factors vascular endothelial growth factor (VEGF), soluble fmslike tyrosine kinase (Flt)-1, and placental growth factor (PlGF) $[158,159]$. Serum from women with preeclampsia also disrupts the membrane localization of cadherin-5, which may decrease the number of adhesion complexes at the cytoplasmic membrane and lead to vascular permeability [160]. It remains to be established whether these particular endothelial responses to serum are also mediated by cytokines.

Despite these numerous findings, some have questioned the idea that the maternal blood stream carries a placental "toxic" factor to the periphery which contributes to systemic maternal endothelial dysfunction, as they failed to find any effect of plasma factors on endothelial gene expression in vitro [161]. It has been suggested that the activation of maternal leukocytes during their uteroplacental passage may instead play an important part in the dissemination of an inflammatory response to the periphery [162]. Leukocyte activation could be triggered by their interaction with locally activated endothelium or placenta. In favor of this hypothesis, it has been shown that endothelial cells incubated with placental syncytiotrophoblast debris release factors, which can activate peripheral blood leukocytes in vitro [163]. It is interesting to note that placental syncytiotrophoblast debris and placentally derived IL-8 are also potent activators of neutrophils, in that they stimulate the formation of neutrophil extracellular traps (NET), made from DNA and granule proteins, by these cells [164]. Large numbers of NETs are indeed present in the intervillous space of preeclamptic placentas, demonstrating the importance of local neutrophil activation in this disease. Thus, two modes of propagation of the inflammatory reaction from the placental site into the maternal periphery, one encompassing soluble factors, among which cytokines, and the other being cell-mediated, are possibly at work in preeclampsia.

\section{Conclusions}

This review has attempted to describe how cytokine networks are affected by pregnancy, and how in return, these networks can affect the success of pregnancy. Cytokines are involved throughout pregnancy, from the implantation of the conceptus to parturition, including placentation, and the maintenance of fetal tolerance. A complete presentation of this large array of cytokine requirements was beyond the scope of the present work. We focused here on the role of placentally produced cytokines on the maternal and fetal events, which are substantially affected in preeclampsia, that is, placental function and maternal inflammatory response to pregnancy. It is clear that placental cytokines integrate into the general maternal cytokine networks to modulate these events, and it is most likely that positive feedback regulatory loops between placental and maternal cells amplify the load of cytokines present in the maternal body, and subsequently, the maternal syndromes. In conclusion, dysregulated cytokine expression by placental cells is certainly one facet of the elusive placental "toxic" factor, or factors, causing the maternal symptoms in preeclampsia.

Acknowledgments This work was supported in part by a grant form the Swiss National Science Foundation (No. 3200-107625).

\section{References}

1. Benirschke K, Kaufmann P (2000) Pathology of the human placenta, 4th edn. Springer, Berlin Heidelberg New York

2. Medawar PB (1961) Immunological tolerance. Nature 189:14-17

3. Redman CW, McMichael AJ, Stirrat GM, Sunderland CA, Ting A (1984) Class 1 major histocompatibility complex antigens on human extra-villous trophoblast. Immunology 52:457-468

4. Kovats S, Main EK, Librach C, Stubblebine M, Fisher SJ, DeMars R (1990) A class I antigen, HLA-G, expressed in human trophoblasts. Science 248:220-223

5. Ishitani A, Sageshima N, Lee N, Dorofeeva N, Hatake K, Marquardt H, Geraghty DE (2003) Protein expression and peptide binding suggest unique and interacting functional roles for HLA-E, F, and $\mathrm{G}$ in maternal-placental immune recognition. J Immunol 171:1376-1384

6. Hunt JS, Petroff MG, McIntire RH, Ober C (2005) HLA-G and immune tolerance in pregnancy. FASEB J 19:681-693

7. Ishitani A, Sageshima N, Hatake K (2006) The involvement of HLA-E and -F in pregnancy. J Reprod Immunol 69:101-113

8. Bulmer JN, Lash GE (2005) Human uterine natural killer cells: a reappraisal. Mol Immunol 42:511-521

9. Saito S, Nishikawa K, Morii T, Enomoto M, Narita N, Motoyoshi K, Ichijo M (1993) Cytokine production by CD16CD56 bright natural killer cells in the human early pregnancy decidua. Int Immunol 5:559-563

10. Hanna J, Goldman-Wohl D, Hamani Y, Avraham I, Greenfield C, Natanson-Yaron S, Prus D, Cohen-Daniel L, Arnon TI, Manaster I, Gazit R, Yutkin V, Benharroch D, Porgador A, Keshet E, Yagel S, Mandelboim O (2006) Decidual NK cells regulate key developmental processes at the human fetalmaternal interface. Nat Med 12:1065-1074

11. Tabiasco J, Rabot M, Aguerre-Girr M, El Costa H, Berrebi A, Parant O, Laskarin G, Juretic K, Bensussan A, Rukavina 
D, Le Bouteiller P (2006) Human decidual NK cells: unique phenotype and functional properties - a review. Placenta 27 (Suppl A):S34-S39

12. van der MA, Lukassen $H G$, van Lierop MJ, Wijnands F, Mosselman S, Braat DD, Joosten I (2004) Membrane-bound HLA-G activates proliferation and interferon-gamma production by uterine natural killer cells. Mol Hum Reprod 10:189-195

13. Hiby SE, Walker JJ, O'Shaughnessy KM, Redman CW, Carrington M, Trowsdale J, Moffett A (2004) Combinations of maternal KIR and fetal HLA-C genes influence the risk of preeclampsia and reproductive success. J Exp Med 200:957-965

14. Wegmann TG, Lin H, Guilbert L, Mosmann TR (1993) Bidirectional cytokine interactions in the maternal-fetal relationship: is successful pregnancy a TH2 phenomenon? Immunol Today 14:353-356

15. Cadet P, Rady PL, Tyring SK, Yandell RB, Hughes TK (1995) Interleukin-10 messenger ribonucleic acid in human placenta: implications of a role for interleukin-10 in fetal allograft protection. Am J Obstet Gynecol 173:25-29

16. Roth I, Corry DB, Locksley RM, Abrams JS, Litton MJ, Fisher SJ (1996) Human placental cytotrophoblasts produce the immunosuppressive cytokine interleukin 10. J Exp Med 184:539-548

17. Moraes-Pinto MI, Vince GS, Flanagan BF, Hart CA, Johnson PM (1997) Localization of IL-4 and IL-4 receptors in the human term placenta, decidua and amniochorionic membranes. Immunology 90:87-94

18. Bennett WA, Lagoo-Deenadayalan S, Stopple JA, Barber WH, Hale E, Brackin MN, Cowan BD (1998) Cytokine expression by first-trimester human chorionic villi. Am J Reprod Immunol 40:309-318

19. Sacks GP, Clover LM, Bainbridge DR, Redman CW, Sargent IL (2001) Flow cytometric measurement of intracellular Th1 and Th2 cytokine production by human villous and extravillous cytotrophoblast. Placenta 22:550-559

20. Dungy LJ, Siddiqi TA, Khan S (1991) Transforming growth factor-beta 1 expression during placental development. Am J Obstet Gynecol 165:853-857

21. Graham CH, Lysiak JJ, McCrae KR, Lala PK (1992) Localization of transforming growth factor-beta at the human fetalmaternal interface: role in trophoblast growth and differentiation. Biol Reprod 46:561-572

22. Ando N, Hirahara F, Fukushima J, Kawamoto S, Okuda K, Funabashi T, Gorai I, Minaguchi H (1998) Differential gene expression of TGF-beta isoforms and TGF-beta receptors during the first trimester of pregnancy at the human maternal-fetal interface. Am J Reprod Immunol 40:48-56

23. Paulesu L, Romagnoli R, Cintorino M, Ricci MG, Garotta G (1994) First trimester human trophoblast expresses both interferon-gamma and interferon-gamma-receptor. $\mathrm{J}$ Reprod Immunol 27:37-48

24. Hanna N, Hanna I, Hleb M, Wagner E, Dougherty J, Balkundi D, Padbury J, Sharma S (2000) Gestational age-dependent expression of IL-10 and its receptor in human placental tissues and isolated cytotrophoblasts. J Immunol 164:5721-5728

25. Marzi M, Vigano A, Trabattoni D, Villa ML, Salvaggio A, Clerici E, Clerici M (1996) Characterization of type 1 and type 2 cytokine production profile in physiologic and pathologic human pregnancy. Clin Exp Immunol 106:127-133

26. Piccinni MP, Beloni L, Livi C, Maggi E, Scarselli G, Romagnani S (1998) Defective production of both leukemia inhibitory factor and type 2 T-helper cytokines by decidual T cells in unexplained recurrent abortions. Nat Med 4:1020-1024

27. Hill JA, Polgar K, Anderson DJ (1995) T-helper 1-type immunity to trophoblast in women with recurrent spontaneous abortion. JAMA 273:1933-1936
28. Raghupathy R (1997) Th1-type immunity is incompatible with successful pregnancy. Immunol Today 18:478-482

29. Chaouat G, Ledee-Bataille N, Dubanchet S, Zourbas S, Sandra O, Martal J (2004) TH1/TH2 paradigm in pregnancy: paradigm lost? Cytokines in pregnancy/early abortion: reexamining the TH1/TH2 paradigm. Int Arch Allergy Immunol 134:93-119

30. Sacks GP, Studena K, Sargent K, Redman CW (1998) Normal pregnancy and preeclampsia both produce inflammatory changes in peripheral blood leukocytes akin to those of sepsis. Am J Obstet Gynecol 179:80-86

31. Naccasha N, Gervasi MT, Chaiworapongsa T, Berman S, Yoon BH, Maymon E, Romero R (2001) Phenotypic and metabolic characteristics of monocytes and granulocytes in normal pregnancy and maternal infection. Am $\mathrm{J}$ Obstet Gynecol 185:1118-1123

32. Sacks G, Sargent I, Redman C (1999) An innate view of human pregnancy. Immunol Today 20:114-118

33. Kupferminc MJ, Peaceman AM, Wigton TR, Tamura RK, Rehnberg KA, Socol ML (1994) Immunoreactive tumor necrosis factor-alpha is elevated in maternal plasma but undetected in amniotic fluid in the second trimester. Am J Obstet Gynecol 171:976-979

34. Austgulen R, Lien E, Liabakk NB, Jacobsen G, Arntzen KJ (1994) Increased levels of cytokines and cytokine activity modifiers in normal pregnancy. Eur J Obstet Gynecol Reprod Biol 57:149-155

35. Sacks GP, Redman CW, Sargent IL (2003) Monocytes are primed to produce the Th1 type cytokine IL-12 in normal human pregnancy: an intracellular flow cytometric analysis of peripheral blood mononuclear cells. Clin Exp Immunol 131:490-497

36. Kameda T, Matsuzaki N, Sawai K, Okada T, Saji F, Matsuda T, Hirano T, Kishimoto T, Tanizawa O (1990) Production of interleukin- 6 by normal human trophoblast. Placenta 11:205213

37. Chen HL, Yang YP, Hu XL, Yelavarthi KK, Fishback JL, Hunt JS (1991) Tumor necrosis factor alpha mRNA and protein are present in human placental and uterine cells at early and late stages of gestation. Am J Pathol 139:327-335

38. Paulesu L, King A, Loke YW, Cintorino M, Bellizzi E, Boraschi D (1991) Immunohistochemical localization of IL-1 alpha and IL-1 beta in normal human placenta. Lymphokine Cytokine Res 10:443-448

39. Hu XL, Yang Y, Hunt JS (1992) Differential distribution of interleukin-1 alpha and interleukin-1 beta proteins in human placentas. J Reprod Immunol 22:257-268

40. Haynes MK, Jackson LG, Tuan RS, Shepley KJ, Smith JB (1993) Cytokine production in first trimester chorionic villi: detection of mRNAs and protein products in situ. Cell Immunol 151:300-308

41. King A, Jokhi PP, Smith SK, Sharkey AM, Loke YW (1995) Screening for cytokine mRNA in human villous and extravillous trophoblasts using the reverse-transcriptase polymerase chain reaction (RT-PCR). Cytokine 7:364-371

42. Kirwan JP, Hauguel-de Mouzon S, Lepercq J, Challier JC, Huston-Presley L, Friedman JE, Kalhan SC, Catalano PM (2002) TNF-alpha is a predictor of insulin resistance in human pregnancy. Diabetes 51:2207-2213

43. Borzychowski AM, Sargent IL, Redman CW (2006) Inflammation and pre-eclampsia. Semin Fetal Neonatal Med 11:309-316

44. Sibai B, Dekker G, Kupferminc M (2005) Pre-eclampsia. Lancet 365:785-799

45. Redman CW, Sargent IL (2005) Latest advances in understanding preeclampsia. Science 308:1592-1594

46. von Dadelszen P, Magee LA, Roberts JM (2003) Subclassification of preeclampsia. Hypertens Pregnancy 22:143-148 
47. Duckitt K, Harrington D (2005) Risk factors for pre-eclampsia at antenatal booking: systematic review of controlled studies. BMJ 330:565

48. van Dijk M, Mulders J, Poutsma A, Konst AA, Lachmeijer AM, Dekker GA, Blankenstein MA, Oudejans CB (2005) Maternal segregation of the Dutch preeclampsia locus at $10 \mathrm{q} 22$ with a new member of the winged helix gene family. Nat Genet 37:514-519

49. Laivuori H (2007) Genetic aspects of preeclampsia. Front Biosci 12:2372-2382

50. Hahn S, Gupta AK, Troeger C, Rusterholz C, Holzgreve W (2006) Disturbances in placental immunology: ready for therapeutic interventions? Springer Semin Immunopathol 27:477-493

51. Sargent IL, Borzychowski AM, Redman CW (2006) Immunoregulation in normal pregnancy and pre-eclampsia: an overview. Reprod Biomed Online 13:680-686

52. Roberts JM, Taylor RN, Musci TJ, Rodgers GM, Hubel CA, McLaughlin MK (1989) Preeclampsia: an endothelial cell disorder. Am J Obstet Gynecol 161:1200-1204

53. Redman CW, Sargent IL (2003) Pre-eclampsia, the placenta and the maternal systemic inflammatory response - a review. Placenta 24(Suppl A):S21-S27

54. Roberts JM, Redman CW (1993) Pre-eclampsia: more than pregnancy-induced hypertension. Lancet 341:1447-1451

55. Hahn S, Holzgreve W (2002) Fetal cells and cell-free fetal DNA in maternal blood: new insights into pre-eclampsia. Hum Reprod Update 8:501-508

56. Goldman-Wohl DS, Ariel I, Greenfield C, Hochner-Celnikier D, Cross J, Fisher S, Yagel S (2000) Lack of human leukocyte antigen-G expression in extravillous trophoblasts is associated with pre-eclampsia. Mol Hum Reprod 6:88-95

57. Yie SM, Li LH, Li YM, Librach C (2004) HLA-G protein concentrations in maternal serum and placental tissue are decreased in preeclampsia. Am J Obstet Gynecol 191:525-529

58. Le Bouteiller P, Pizzato N, Barakonyi A, Solier C (2003) HLAG, pre-eclampsia, immunity and vascular events. J Reprod Immunol 59:219-234

59. Parham P (2004) NK cells and trophoblasts: partners in pregnancy. J Exp Med 200:951-955

60. Reister F, Frank HG, Heyl W, Kosanke G, Huppertz B, Schroder W, Kaufmann P, Rath W (1999) The distribution of macrophages in spiral arteries of the placental bed in pre-eclampsia differs from that in healthy patients. Placenta 20:229-233

61. Redline RW (2001) Macrophages in the basal plate of preeclamptic placentae. Placenta 22:890-893

62. Burk MR, Troeger C, Brinkhaus R, Holzgreve W, Hahn S (2001) Severely reduced presence of tissue macrophages in the basal plate of pre-eclamptic placentae. Placenta 22:309-316

63. Reister F, Frank HG, Kingdom JC, Heyl W, Kaufmann P, Rath W, Huppertz B (2001) Macrophage-induced apoptosis limits endovascular trophoblast invasion in the uterine wall of preeclamptic women. Lab Invest 81:1143-1152

64. DiFederico E, Genbacev O, Fisher SJ (1999) Preeclampsia is associated with widespread apoptosis of placental cytotrophoblasts within the uterine wall. Am J Pathol 155:293-301

65. Robertson WB, Brosens I, Dixon G (1976) Maternal uterine vascular lesions in the hypertensive complications of pregnancy. Perspect Nephrol Hypertens 5:115-127

66. Graham CH, Burton GJ (2004) Oxygen and trophoblast behaviour-a workshop report. Placenta 25(Suppl A):S90-S92

67. Burton GJ, Caniggia I (2001) Hypoxia: implications for implantation to delivery-a workshop report. Placenta 22(Suppl A):S63-S65

68. Soleymanlou N, Jurisica I, Nevo O, Ietta F, Zhang X, Zamudio S, Post M, Caniggia I (2005) Molecular evidence of placental hypoxia in preeclampsia. J Clin Endocrinol Metab 90:4299-4308
69. Hung TH, Skepper JN, Burton GJ (2001) In vitro ischemiareperfusion injury in term human placenta as a model for oxidative stress in pathological pregnancies. Am J Pathol 159:1031-1043

70. Sikkema JM, van Rijn BB, Franx A, Bruinse HW, de Roos R, Stroes ES, van Faassen EE (2001) Placenta 1 superoxide is increased in pre-eclampsia. Placenta 22:304-308

71. Many A, Hubel CA, Fisher SJ, Roberts JM, Zhou Y (2000) Invasive cytotrophoblasts manifest evidence of oxidative stress in preeclampsia. Am J Pathol 156:321-331

72. Wang Y, Walsh SW (2001) Increased superoxide generation is associated with decreased superoxide dismutase activity and mRNA expression in placental trophoblast cells in pre-eclampsia. Placenta 22:206-212

73. Vanderlelie J, Venardos K, Clifton VL, Gude NM, Clarke FM, Perkins AV (2005) Increased biological oxidation and reduced anti-oxidant enzyme activity in pre-eclamptic placentae. Placenta 26:53-58

74. Burton GJ, Jauniaux E (2004) Placental oxidative stress: from miscarriage to preeclampsia. J Soc Gynecol Investig 11:342-352

75. Vaughan JE, Walsh SW (2002) Oxidative stress reproduces placental abnormalities of preeclampsia. Hypertens Pregnancy 21:205-223

76. Leung DN, Smith SC, To KF, Sahota DS, Baker PN (2001) Increased placental apoptosis in pregnancies complicated by preeclampsia. Am J Obstet Gynecol 184:1249-1250

77. Ishihara N, Matsuo $\mathrm{H}$, Murakoshi $\mathrm{H}$, Laoag-Fernandez JB, Samoto T, Maruo T (2002) Increased apoptosis in the syncytiotrophoblast in human term placentas complicated by either preeclampsia or intrauterine growth retardation. Am J Obstet Gynecol 186:158-166

78. Levy R, Smith SD, Chandler K, Sadovsky Y, Nelson DM (2000) Apoptosis in human cultured trophoblasts is enhanced by hypoxia and diminished by epidermal growth factor. Am J Physiol Cell Physiol 278:C982-C988

79. Hung TH, Skepper JN, Charnock-Jones DS, Burton GJ (2002) Hypoxia-reoxygenation: a potent inducer of apoptotic changes in the human placenta and possible etiological factor in preeclampsia. Circ Res 90:1274-1281

80. Huppertz B, Kingdom J, Caniggia I, Desoye G, Black S, Korr H, Kaufmann P (2003) Hypoxia favours necrotic versus apoptotic shedding of placental syncytiotrophoblast into the maternal circulation. Placenta 24:181-190

81. Redman CW, Sargent IL (2000) Placental debris, oxidative stress and pre-eclampsia. Placenta 21:597-602

82. Lo YM, Leung TN, Tein MS, Sargent IL, Zhang J, Lau TK, Haines CJ, Redman CW (1999) Quantitative abnormalities of fetal DNA in maternal serum in preeclampsia. Clin Chem 45: 184-188

83. Zhong XY, Laivuori H, Livingston JC, Ylikorkala O, Sibai BM, Holzgreve W, Hahn S (2001) Elevation of both maternal and fetal extracellular circulating deoxyribonucleic acid concentrations in the plasma of pregnant women with preeclampsia. Am J Obstet Gynecol 184:414-419

84. Knight M, Redman CW, Linton EA, Sargent IL (1998) Shedding of syncytiotrophoblast microvilli into the maternal circulation in pre-eclamptic pregnancies. Br J Obstet Gynaecol 105:632-640

85. Goswami D, Tannetta DS, Magee LA, Fuchisawa A, Redman CW, Sargent IL, von Dadelszen P (2006) Excess syncytiotrophoblast microparticle shedding is a feature of early-onset preeclampsia, but not normotensive intrauterine growth restriction. Placenta 27:56-61

86. Saito S, Umekage H, Sakamoto Y, Sakai M, Tanebe K, Sasaki Y, Morikawa H (1999) Increased T-helper-1-type immunity and decreased T-helper-2-type immunity in patients with preeclampsia. Am J Reprod Immunol 41:297-306 
87. Darmochwal-Kolarz D, Leszczynska-Gorzelak B, Rolinski J, Oleszczuk J (1999) T helper 1- and T helper 2-type cytokine imbalance in pregnant women with pre-eclampsia. Eur J Obstet Gynecol Reprod Biol 86:165-170

88. Rein DT, Schondorf T, Gohring UJ, Kurbacher CM, Pinto I, Breidenbach M, Mallmann P, Kolhagen H, Engel H (2002) Cytokine expression in peripheral blood lymphocytes indicates a switch to T(HELPER) cells in patients with preeclampsia. J Reprod Immunol 54:133-142

89. Sakai M, Tsuda H, Tanebe K, Sasaki Y, Saito S (2002) Interleukin-12 secretion by peripheral blood mononuclear cells is decreased in normal pregnant subjects and increased in preeclamptic patients. Am J Reprod Immunol 47:91-97

90. Wilczynski JR, Tchorzewski H, Glowacka E, Banasik M, Lewkowicz P, Szpakowski M, Zeman K, Wilczynski J (2002) Cytokine secretion by decidual lymphocytes in transient hypertension of pregnancy and pre-eclampsia. Mediators Inflamm 11:105-111

91. Orange S, Horvath J, Hennessy A (2003) Preeclampsia is associated with a reduced interleukin-10 production from peripheral blood mononuclear cells. Hypertens Pregnancy 22: $1-8$

92. Jonsson Y, Matthiesen L, Berg G, Ernerudh J, Nieminen K, Ekerfelt $C$ (2005) Indications of an altered immune balance in preeclampsia: a decrease in in vitro secretion of IL-5 and IL-10 from blood mononuclear cells and in blood basophil counts compared with normal pregnancy. J Reprod Immunol 66:69-84

93. Holthe MR, Staff AC, Berge LN, Lyberg T (2004) Leukocyte adhesion molecules and reactive oxygen species in preeclampsia. Obstet Gynecol 103:913-922

94. Luppi P, Deloia JA (2006) Monocytes of preeclamptic women spontaneously synthesize pro-inflammatory cytokines. Clin Immunol 118:268-275

95. Kupferminc MJ, Peaceman AM, Wigton TR, Rehnberg KA, Socol ML (1994) Tumor necrosis factor-alpha is elevated in plasma and amniotic fluid of patients with severe preeclampsia. Am J Obstet Gynecol 170:1752-1757

96. Greer IA, Lyall F, Perera T, Boswell F, Macara LM (1994) Increased concentrations of cytokines interleukin- 6 and interleukin-1 receptor antagonist in plasma of women with preeclampsia: a mechanism for endothelial dysfunction? Obstet Gynecol 84:937-940

97. Vince GS, Starkey PM, Austgulen R, Kwiatkowski D, Redman CW (1995) Interleukin-6, tumour necrosis factor and soluble tumour necrosis factor receptors in women with pre-eclampsia. Br J Obstet Gynaecol 102:20-25

98. Conrad KP, Miles TM, Benyo DF (1998) Circulating levels of immunoreactive cytokines in women with preeclampsia. Am J Reprod Immunol 40:102-111

99. Stallmach T, Hebisch G, Joller H, Kolditz P, Engelmann M (1995) Expression pattern of cytokines in the different compartments of the feto-maternal unit under various conditions. Reprod Fertil Dev 7:1573-1580

100. Kupferminc MJ, Peaceman AM, Aderka D, Wallach D, Socol ML (1996) Soluble tumor necrosis factor receptors and interleukin-6 levels in patients with severe preeclampsia. Obstet Gynecol $88: 420-427$

101. Kauma S, Takacs P, Scordalakes C, Walsh S, Green K, Peng T (2002) Increased endothelial monocyte chemoattractant protein-1 and interleukin-8 in preeclampsia. Obstet Gynecol 100:706-714

102. Adams KM, Mandel LS, Guthrie KA, Atkinson MW (2003) Interleukin-18 in the plasma of women with preeclampsia. Am J Obstet Gynecol 188:1234-1237

103. Bachmayer N, Rafik HR, Liszka L, Bremme K, SverremarkEkstrom E (2006) Aberrant uterine natural killer (NK)-cell expression and altered placental and serum levels of the NK- cell promoting cytokine interleukin-12 in pre-eclampsia. Am J Reprod Immunol 56:292-301

104. Jonsson Y, Ruber M, Matthiesen L, Berg G, Nieminen K, Sharma S, Ernerudh J, Ekerfelt C (2006) Cytokine mapping of sera from women with preeclampsia and normal pregnancies. J Reprod Immunol 70:83-91

105. Opsjon SL, Austgulen R, Waage A (1995) Interleukin-1, interleukin-6 and tumor necrosis factor at delivery in preeclamptic disorders. Acta Obstet Gynecol Scand 74:19-26

106. Agarwal R, Loganath A, Roy AC, Wong YC, Ng SC (2001) Expression profiles of interleukin-15 in early and late gestational human placenta and in pre-eclamptic placenta. Mol Hum Reprod 7:97-101

107. Wang Y, Walsh SW (1996) TNF alpha concentrations and mRNA expression are increased in preeclamptic placentas. J Reprod Immunol 32:157-169

108. Rinehart BK, Terrone DA, Lagoo-Deenadayalan S, Barber WH, Hale EA, Martin JN Jr, Bennett WA (1999) Expression of the placental cytokines tumor necrosis factor alpha, interleukin 1beta, and interleukin 10 is increased in preeclampsia. Am J Obstet Gynecol 181:915-920

109. Munno I, Chiechi LM, Lacedra G, Putignano G, Patimo C, Lobascio A, Loizzi P (1999) Spontaneous and induced release of prostaglandins, interleukin (IL)-1beta, IL-6, and tumor necrosis factor-alpha by placental tissue from normal and preeclamptic pregnancies. Am J Reprod Immunol 42:369-374

110. Banerjee S, Smallwood A, Moorhead J, Chambers AE, Papageorghiou A, Campbell S, Nicolaides K (2005) Placental expression of interferon-gamma (IFN-gamma) and its receptor IFN-gamma R2 fail to switch from early hypoxic to late normotensive development in preeclampsia. J Clin Endocrinol Metab 90:944-952

111. Benyo DF, Miles TM, Conrad KP (1997) Hypoxia stimulates cytokine production by villous explants from the human placenta. J Clin Endocrinol Metab 82:1582-1588

112. Malek A, Sager R, Schneider H (2001) Effect of hypoxia, oxidative stress and lipopolysaccharides on the release of prostaglandins and cytokines from human term placental explants. Placenta 22(Suppl A):S45-S50

113. Benyo DF, Smarason A, Redman CW, Sims C, Conrad KP (2001) Expression of inflammatory cytokines in placentas from women with preeclampsia. J Clin Endocrinol Metab $86: 2505-2512$

114. Hung TH, Charnock-Jones DS, Skepper JN, Burton GJ (2004) Secretion of tumor necrosis factor-alpha from human placental tissues induced by hypoxia-reoxygenation causes endothelial cell activation in vitro: a potential mediator of the inflammatory response in preeclampsia. Am J Pathol 164:1049-1061

115. Poston L, Briley AL, Seed PT, Kelly FJ, Shennan AH (2006) Vitamin $\mathrm{C}$ and vitamin $\mathrm{E}$ in pregnant women at risk for preeclampsia (VIP trial): randomised placebo-controlled trial. Lancet 367:1145-1154

116. Rumbold AR, Crowther CA, Haslam RR, Dekker GA, Robinson JS (2006) Vitamins $\mathrm{C}$ and $\mathrm{E}$ and the risks of preeclampsia and perinatal complications. $\mathrm{N}$ Engl $\mathrm{J}$ Med 354:1796-1806

117. Bowen RS, Gu Y, Zhang Y, Lewis DF, Wang Y (2005) Hypoxia promotes interleukin- 6 and -8 but reduces interleukin-10 production by placental trophoblast cells from preeclamptic pregnancies. J Soc Gynecol Investig 12:428-432

118. Kauma SW, Wang Y, Walsh SW (1995) Preeclampsia is associated with decreased placental interleukin- 6 production. J Soc Gynecol Investig 2:614-617

119. Hennessy A, Pilmore HL, Simmons LA, Painter DM (1999) A deficiency of placental IL-10 in preeclampsia. J Immunol 163:3491-3495 
120. Rein DT, Breidenbach M, Honscheid B, Friebe-Hoffmann U, Engel H, Gohring UJ, Uekermann L, Kurbacher CM, Schondorf T (2003) Preeclamptic women are deficient of interleukin-10 as assessed by cytokine release of trophoblast cells in vitro. Cytokine 23:119-125

121. Caniggia I, Mostachfi H, Winter J, Gassmann M, Lye SJ, Kuliszewski M, Post M (2000) Hypoxia-inducible factor-1 mediates the biological effects of oxygen on human trophoblast differentiation through TGFbeta(3). J Clin Invest 105:577-587

122. Caniggia I, Grisaru-Gravnosky S, Kuliszewsky M, Post M, Lye SJ (1999) Inhibition of TGF-beta 3 restores the invasive capability of extravillous trophoblasts in preeclamptic pregnancies. J Clin Invest 103:1641-1650

123. Zhou Y, Damsky CH, Fisher SJ (1997) Preeclampsia is associated with failure of human cytotrophoblasts to mimic a vascular adhesion phenotype. One cause of defective endovascular invasion in this syndrome? J Clin Invest 99:2152-2164

124. Reister F, Kingdom JC, Ruck P, Marzusch K, Heyl W, Pauer U, Kaufmann P, Rath W, Huppertz B (2006) Altered protease expression by periarterial trophoblast cells in severe early-onset preeclampsia with IUGR. J Perinat Med 34:272-279

125. Kharfi A, Giguere Y, Sapin V, Masse J, Dastugue B, Forest JC (2003) Trophoblastic remodeling in normal and preeclamptic pregnancies: implication of cytokines. Clin Biochem 36:323-331

126. Staun-Ram E, Shalev E (2005) Human trophoblast function during the implantation process. Reprod Biol Endocrinol 3:56

127. Zhou Y, Genbacev O, Damsky CH, Fisher SJ (1998) Oxygen regulates human cytotrophoblast differentiation and invasion: implications for endovascular invasion in normal pregnancy and in pre-eclampsia. J Reprod Immunol 39:197-213

128. Meisser A, Chardonnens D, Campana A, Bischof P (1999) Effects of tumour necrosis factor-alpha, interleukin-1 alpha, macrophage colony stimulating factor and transforming growth factor beta on trophoblastic matrix metalloproteinases. Mol Hum Reprod 5:252-260

129. Meisser A, Cameo P, Islami D, Campana A, Bischof P (1999) Effects of interleukin-6 (IL-6) on cytotrophoblastic cells. Mol Hum Reprod 5:1055-1058

130. Librach CL, Feigenbaum SL, Bass KE, Cui TY, Verastas N, Sadovsky Y, Quigley JP, French DL, Fisher SJ (1994) Interleukin-1 beta regulates human cytotrophoblast metalloproteinase activity and invasion in vitro. J Biol Chem 269:17125-17131

131. Roth I, Fisher SJ (1999) IL-10 is an autocrine inhibitor of human placental cytotrophoblast MMP-9 production and invasion. Dev Biol 205:194-204

132. Lash GE, Otun HA, Innes BA, Bulmer JN, Searle RF, Robson SC (2005) Inhibition of trophoblast cell invasion by TGFB1, 2, and 3 is associated with a decrease in active proteases. Biol Reprod 73:374-381

133. Yui J, Garcia-Lloret M, Wegmann TG, Guilbert LJ (1994) Cytotoxicity of tumour necrosis factor-alpha and gammainterferon against primary human placental trophoblasts. Placenta $15: 819-835$

134. Crocker IP, Barratt S, Kaur M, Baker PN (2001) The in-vitro characterization of induced apoptosis in placental cytotrophoblasts and syncytiotrophoblasts. Placenta 22:822-830

135. Bauer S, Pollheimer J, Hartmann J, Husslein P, Aplin JD, Knofler M (2004) Tumor necrosis factor-alpha inhibits trophoblast migration through elevation of plasminogen activator inhibitor-1 in first-trimester villous explant cultures. J Clin Endocrinol Metab 89:812-822

136. Renaud SJ, Postovit LM, Macdonald-Goodfellow SK, McDonald GT, Caldwell JD, Graham CH (2005) Activated macrophages inhibit human cytotrophoblast invasiveness in vitro. Biol Reprod $73: 237-243$
137. Crocker IP, Tansinda DM, Jones CJ, Baker PN (2004) The influence of oxygen and tumor necrosis factor-alpha on the cellular kinetics of term placental villous explants in culture. $\mathrm{J}$ Histochem Cytochem 52:749-757

138. Leisser C, Saleh L, Haider S, Husslein H, Sonderegger S, Knofler M (2006) Tumour necrosis factor-alpha impairs chorionic gonadotrophin beta-subunit expression and cell fusion of human villous cytotrophoblast. Mol Hum Reprod 12:601-609

139. Garcia-Lloret MI, Winkler-Lowen B, Guilbert LJ (2000) Monocytes adhering by LFA-1 to placental syncytiotrophoblasts induce local apoptosis via release of TNF-alpha. A model for hematogenous initiation of placental inflammations. J Leukoc Biol 68:903-908

140. Hauguel-de Mouzon S, Guerre-Millo M (2006) The placenta cytokine network and inflammatory signals. Placenta 27:794 798

141. Goodwin VJ, Sato TA, Mitchell MD, Keelan JA (1998) Antiinflammatory effects of interleukin-4, interleukin-10, and transforming growth factor-beta on human placental cells in vitro. Am J Reprod Immunol 40:319-325

142. Moreau P, Adrian-Cabestre F, Menier C, Guiard V, Gourand L, Dausset J, Carosella ED, Paul P (1999) IL-10 selectively induces HLA-G expression in human trophoblasts and monocytes. Int Immunol 11:803-811

143. Stallmach T, Hebisch G, Orban P, Lu X (1999) Aberrant positioning of trophoblast and lymphocytes in the feto-maternal interface with pre-eclampsia. Virchows Arch 434:207-211

144. Wilczynski JR, Tchorzewski H, Banasik M, Glowacka E, Wieczorek A, Lewkowicz P, Malinowski A, Szpakowski M, Wilczynski J (2003) Lymphocyte subset distribution and cytokine secretion in third trimester decidua in normal pregnancy and preeclampsia. Eur J Obstet Gynecol Reprod Biol 109:8-15

145. Nishino E, Matsuzaki N, Masuhiro K, Kameda T, Taniguchi T, Takagi T, Saji F, Tanizawa O (1990) Trophoblast-derived interleukin-6 (IL-6) regulates human chorionic gonadotropin release through IL-6 receptor on human trophoblasts. J Clin Endocrinol Metab 71:436-441

146. Heikkinen J, Mottonen M, Alanen A, Lassila O (2004) Phenotypic characterization of regulatory $\mathrm{T}$ cells in the human decidua. Clin Exp Immunol 136:373-378

147. Read S, Powrie F (2001) CD4(+) regulatory T cells. Curr Opin Immunol 13:644-649

148. Zenclussen AC (2006) Regulatory T cells in pregnancy. Springer Semin Immunopathol 28:31-39

149. Paeschke S, Chen F, Horn N, Fotopoulou C, Zambon-Bertoja A, Sollwedel A, Zenclussen ML, Casalis PA, Dudenhausen JW, Volk HD, Zenclussen AC (2005) Pre-eclampsia is not associated with changes in the levels of regulatory $\mathrm{T}$ cells in peripheral blood. Am J Reprod Immunol 54:384-389

150. Valencia X, Stephens G, Goldbach-Mansky R, Wilson M, Shevach EM, Lipsky PE (2006) TNF downmodulates the function of human $\mathrm{CD} 4+\mathrm{CD} 25 \mathrm{hi}$ T-regulatory cells. Blood 108:253-261

151. Mantovani A, Bussolino F, Introna M (1997) Cytokine regulation of endothelial cell function: from molecular level to the bedside. Immunol Today 18:231-240

152. Rusterholz C, Gupta AK, Huppertz B, Holzgreve W, Hahn S (2005) Soluble factors released by placental villous tissue: interleukin-1 is a potential mediator of endothelial dysfunction. Am J Obstet Gynecol 192:618-624

153. Austgulen R, Lien E, Vince G, Redman CW (1997) Increased maternal plasma levels of soluble adhesion molecules (ICAM-1, VCAM-1, E-selectin) in preeclampsia. Eur J Obstet Gynecol Reprod Biol 71:53-58

154. Heyl W, Handt S, Reister F, Gehlen J, Mittermayer C, Rath W (1999) The role of soluble adhesion molecules in evaluating 
endothelial cell activation in preeclampsia. Am J Obstet Gynecol 180:68-72

155. Takacs P, Green KL, Nikaeo A, Kauma SW (2003) Increased vascular endothelial cell production of interleukin-6 in severe preeclampsia. Am J Obstet Gynecol 188:740-744

156. Scalera F, Schlembach D, Beinder E (2001) Production of vasoactive substances by human umbilical vein endothelial cells after incubation with serum from preeclamptic patients. Eur J Obstet Gynecol Reprod Biol 99:172-178

157. Winn HN, Todd HM, Amon E, al Malt A, Molnar M, Hertelendy F (1997) Effects of serum from preeclamptic women on prostacyclin production by human endothelial cells. J Matern Fetal Med 6:249-253

158. Maynard SE, Min JY, Merchan J, Lim KH, Li J, Mondal S, Libermann TA, Morgan JP, Sellke FW, Stillman IE, Epstein FH, Sukhatme VP, Karumanchi SA (2003) Excess placental soluble fms-like tyrosine kinase 1 (sFlt1) may contribute to endothelial dysfunction, hypertension, and proteinuria in preeclampsia. J Clin Invest 111:649-658

159. Levine RJ, Karumanchi SA (2005) Circulating angiogenic factors in preeclampsia. Clin Obstet Gynecol 48:372-386
160. Groten T, Kreienberg R, Fialka I, Huber L, Wedlich D (2000) Altered subcellular distribution of cadherin-5 in endothelial cells caused by the serum of pre-eclamptic patients. Mol Hum Reprod 6:1027-1032

161. Donker RB, Asgeirsdottir SA, Gerbens F, van Pampus MG, Kallenberg CG, te Meerman GJ, Aarnoudse JG, Molema G (2005) Plasma factors in severe early-onset preeclampsia do not substantially alter endothelial gene expression in vitro. J Soc Gynecol Investig 12:98-106

162. Mellembakken JR, Aukrust P, Olafsen MK, Ueland T, Hestdal K, Videm V (2002) Activation of leukocytes during the uteroplacental passage in preeclampsia. Hypertension 39:155-160

163. von Dadelszen P, Hurst G, Redman CW (1999) Supernatants from co-cultured endothelial cells and syncytiotrophoblast microvillous membranes activate peripheral blood leukocytes in vitro. Hum Reprod 14:919-924

164. Gupta AK, Hasler P, Holzgreve W, Gebhardt S, Hahn S (2005) Induction of neutrophil extracellular DNA lattices by placental microparticles and IL-8 and their presence in preeclampsia. Hum Immunol 66:1146-1154 